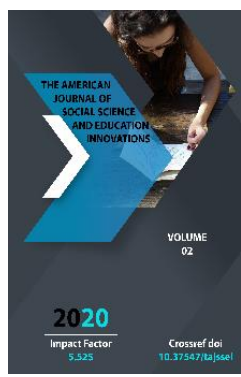

\title{
Academician Ibrahim Muminov - Organizer Of The First Uzbek Encyclopedia
}

Temur Muminov

PhD Student, National University Of Uzbekistan

Copyright: Original content from this work may be used under the terms of the creative commons attributes 4.0 licence.

\section{ABSTRACT}

This article tells about the life of academician Ibrahim Muminov, who was the Vice President of the Academy of Sciences of Uzbekistan for eighteen years and led the development of history, philosophy, literature, culture and art.

It is written about his role as an enlightened, patriotic, nationalist scientist in the creation of the Uzbek Soviet encyclopedia, which is a reflection of the centuries-old culture of our people. The author provides a detailed analysis of the problems, difficulties and contradictions in the creation of the National Encyclopedia.

\section{KEYWORDS}

Culture, Spirituality, Philosophy, Natural Sciences, Academy of Sciences of Uzbekistan, Uzbek Soviet Encyclopedia, Cultural Heritage, Intellectuals.

\section{INTRODUCTION}

The life and scientific activity of Uzbek intellectuals during the Soviet era were extremely controversial. Hundreds of patriotic and nationalist scholars Mahmudhoja Behbudi, Munavvar qori, Abdurauf Fitrat, Abdulla Avloni, Pulat Soliev, Otajon Hashim, Sattor Jabbor were thrown into the mill of repression. Soviet policy and ideology were extremely frightened by the recognition of national identity. The original children of the people were brutally annihilated as "nationalists" and enemies of the people. [1] 
There is a saying among our people: "A flowing river flows". In the second half of the twentieth century, under the heavy ideological pressure of Soviet colonialism, Habib Abdullaev, Hamid Sulaymon, Vahid Zohidov, Ibrahim Muminov, Obid Sodikov, Vosik Kobulov, Tesha Zohidov, Sadi Sirojiddinov, Yolkin Turakulov, Aziz Qayumov, Hamid Ziyaib, Hamid Ziyaib, came out. They played an important role in the spread of Uzbek science around the world (for example, academician Yolkin Turakulov was a recipient of the Lenin Prize, which is rarely awarded to scientists).

The life of academician Ibrahim Muminov, one of the brightest representatives of this science in our science, and his selfless contribution to the rapprochement of national independence are exemplary. Those who knew him intimately wrote heartfelt memoirs that the students were generous, tolerant, honest and simple Uzbek scholars. [2]

\section{THE MAIN PART}

Ibrahim Muminov has mastered the ideological shells of his time and finished the works about the masterpieces of our national heritage. Even in his work "Let's study deeply the philosophical heritage of V.I. Lenin" [3] he decided to write about Heraclitus, Democritus, Aristotle, Epicurus, Ibn Sino, Abu Rayhan Beruni, Ulugbek, Alisher Navoi.

The teacher (whose students have always referred to him as such) was considered to have an encyclopedic knowledge in the field of social sciences. It would be unfair not to acknowledge his special services in the selection of good, talented scholars in the fields of national philosophy, history, literature, economics, logic, linguistics, and art history. Ibrahim Muminov has trained one hundred candidates of sciences and twenty doctors of sciences. "Thus, Ibrahim Muminov came to School of Philosophy - a school with a whole system. The school developed not in arithmetic, but in geometric progression, and became the scientific center of Uzbek philosophy in the twentieth century. "[4]

Later Muzaffar Khairullaev, Said Shermuhamedov, Haydar Pulatov, Omonullo Fayzullaev, Anvar Sharipov emerged from this school as prominent representatives of Uzbek science.

The ideology wrapped in a network of chauvinistic ideas has never stopped condemning people like Amir Temur in our national history. Amir Temur, as a factor that awakened the familiar nation, always alerted the officials of that time. In such a difficult situation, at a time of increasing persecution and oppression, the nationalist, truthful scholar Ibrahim Muminov dared to write the history of Amir Temur. His pamphlet "The place and role of Amir Temur in the history of Central Asia" [5] gave a great impetus to our national intelligentsia. He inspired them. This courage of Ibrahim Muminov was literally the courage of the great Sahibkiran Amir Temur. With this pamphlet, the teacher is at the forefront of our Timurid studies. However, Ibrahim Muminov was soon accused of idealizing Amir Temur. M.Vahobov, M.Abduraimov, R.Nabiev, who tried to raise the name of Temur, slandered one intellectual. As a result, as a manifestation of these protests and attacks, authoritative and threatening articles against I. Muminov were published in Moscow. [6]

Researcher Ibrahim was persecuted for writing the truth of history. Imam al-Ghazali's wise words, "The wise will be truthful, so they will always live in suffering, persecution and oppression," reflect the harsh social environment and policy of violence that has taken various forms in all ages. [7]

Ibrahim Muminov was one of the main organizers and initiators of the creation of the Encyclopedia, a mirror of Uzbek history. The 9th volume of the Uzbek Soviet Encyclopedia was published under the direction of 
researcher Ibrahim Muminov and was sealed as an important event in our social life.

One of the tragedies of the twentieth century was the encroachment on this historical memory. With the idea of creating a single Soviet people, he decided to create a completely "new history." Especially during this period, the "violence" against the social sciences and humanities intensified, making them a "model" of communist ideology. Discrimination and falsification of the rich history, national culture and values of the Uzbek people were rampant in those years. The study of our ancient history has been condemned as "worship of the past". Sociologists were given a special "instruction" to study the period of "advanced socialism", its "historical significance" and "advantages". [8]

In such a difficult and dangerous period, I. Muminov masterfully works in such a way as to enrich the national identity, first of all, in order to develop internationalism. As a result, the great thinkers of our national history will study the scientific heritage and promote it widely. Holds international scientific-theoretical conferences.

The policy of the close maze has undergone many changes. These events can be studied today on the basis of the principles of objectivity, truthfulness and historicity. Indeed, in recent years a lot of one-sided literature about the Soviet era has been written.

The best source on the life and work of Ibrahim Muminov is his own work. [9] In addition, these works give the spirit of their time. Today we have the opportunity to fully explore every page of our history. Justice was served and scientific dissertations were written about the teacher. [10]

The memories of his contemporaries and students are invaluable for a deeper understanding of Ibrahim Muminov's personality. Well-known scientists Omonulla
Fayzullaev, Gaybulla Salomov, Naim Goibov and Hamid Ziyaev wrote very sincerely about the qualities of a scientist, organization, honesty, humanity and nationalism. [11]

One of the tragedies of the twentieth century was the encroachment on this historical memory. With the idea of creating a single Soviet people, he decided to create a completely "new history." Especially during this period, the "violence" against the social sciences and humanities intensified, making them a "model" of communist ideology. Discrimination and falsification of the rich history, national culture and values of the Uzbek people were rampant in those years. The study of our ancient history has been condemned as "worship of the past". Sociologists were given a special "instruction" to study the period of "advanced socialism", its "historical significance" and "advantages". [8]

In such a difficult and dangerous period, I. Muminov masterfully works in such a way as to enrich the national identity, first of all, in order to develop internationalism. As a result, the great thinkers of our national history will study the scientific heritage and promote it widely. Holds international scientific-theoretical conferences.

The policy of the close maze has undergone many changes. These events can be studied today on the basis of the principles of objectivity, truthfulness and historicity. Indeed, in recent years a lot of one-sided literature about the Soviet era has been written.

The best source on the life and work of Ibrahim Muminov is his own work. [9] In addition, these works give the spirit of their time. Today we have the opportunity to fully explore every page of our history. Justice was served and scientific dissertations were written about the teacher. [10]

The memories of his contemporaries and students are invaluable for a deeper 
understanding of Ibrahim Muminov's personality. Well-known scientists Omonulla Fayzullaev, Gaybulla Salomov, Naim Goibov and Hamid Ziyaev wrote very sincerely about the qualities of a scientist, organization, honesty, humanity and nationalism. [11]

In addition, the archives of the Academy of Sciences of Uzbekistan contain many archival documents related to the activities of $\mathrm{I}$. Muminov. In 1961, the encyclopedia sector was opened at the Institute of Language and Literature of the Academy of Sciences of Uzbekistan, where scientists studied the experience of the Great Soviet Encyclopedia and the Ukrainian Soviet Encyclopedia. From 1965 to 1966, the Presidium of the Academy of Sciences of Uzbekistan established the Department of Physical, Mathematical and Technical Sciences, the Department of Chemistry and Biology, the Department of Soil Science, the Department of Medicine, the Department of Social Sciences (History, Philosophy, Language, Literature, Art). was headed by eminent scientists of the sciences. In the section of language, literature and folklore of the Department of Social Sciences Homil Yakubov, Gulom Karimov, Mahmudali Yunusov (son of the famous orientalist Yunus Hakimjanov, who led the preparation of the Persian facsimile copy of Sharofiddin Ali Yazdi's "Zafarnoma" for publication), Laziz Qayumov (literary theory), Ortiq Qayumov Ismatilla Abdullaev, Sabohat Azimjanova, Boriboy Ahmedov, Hamid Ziyoev, Ubaydulla Karimov, Bakhriddin Mannonov, Hamidulla Hikmatullaev, Meli Ahunova, in the section of archeology, ethnography, anthropology, in the section of philosophy and atheism. , In the fraternal republics such as the USSR and Uzbekistan, these departments were abolished during the perestroika) Abdulla Ayupov, Mubin Baratov, Mutallib Usmanov and others.

In the main edition of the Uzbek Soviet encyclopedia A.Shomahmudov, U.Ahrorov, P.Turaev, D.Shorahmedov, S.Musaev,
M.Aminov, Sh.Yunusov, Ya.Shermuhamedov, G.Salomov, Sh.Siddikov, U.Fayzieva, D .Fayzirahmanov and others worked. The editorial board of UzSE, which approves the work of these scientific and literary editors, is headed by Vahid Abdullaev, Gani Abdurahmanov, Rustam Abdushukurov, Sarvar Azimov, Sulaymon Azimov, Obid Akramkhodjaev, Rahima Aminova, Ahmadali Askarov, Mukhtor Ashrafiy, Muqaddima Ashrafov, Vavlon Vahoho. Zohidov, Muhammadjon Yuldashev, Malik Nabiev, Komil Nu'manov (Yashin), Ubay Orifov, Haydar Pulatov, Hamid Sulaymonov, Sa'di Sirojiddinov, Obid Sodiqov, Izzat Sultanov, Yusuf Sultanov, Ural Tansiqbaev (painter), Yolkin Turakulov, Shoahmad Shohondu, There were worldrenowned intellectuals such as V.Shcheglov (astronomer), Erkin Yusupov, Shavkat Urazaev, Vosil Kobulov, Yahyo Gulomov, Ibrahim Hamroboev, Khabibulla Hasanov. The absence of the name of the President of the Academy of Sciences of Uzbekistan Habib Abdullayev among them surprises the current generation. In those years (1965-1975), this scientist, who paved the way for world-famous scientists, was fired by the colonialists of the All-Union as a "nationalist who increased the number of national cadres" and his property was confiscated.

The preparation and publication of the 14th volume of the Uzbek Soviet encyclopedia under the leadership of Ibrahim Muminov as a treasure trove of valuable knowledge in all sciences has become a mirror and treasure of the great culture of the Uzbek people. Brockhaus and Efron, Oxford, Berlin, France, Russia, Ukraine encyclopedias, Turkish encyclopedias "Qomusul-alam" and "Islamic encyclopedia" were also used in the preparation of UzSE.

The Academy of Sciences of Uzbekistan has been preparing for the publication of the Encyclopedia for decades. When I. Muminov became the editor-in-chief of the editorial office, the work was carried out in spite of the 
Tashkent earthquake, which accelerated the work. "They demanded to do things that had not been done for years ... in a week or a few days," wrote Gaybullah as-Salam, a student of I. Muminov. There is an earthquake of 7-8 magnitude below us, everyone is confused ... We are crazy! We burn in the encyclopedia. Only the dreamy, courageous people of the third could dare to do so. Here is the layout of the first volume. Size 92 printing plate. Date of dialing: 1 10.67. Published: 18.10 .67 . published in eighteen days ... We noticed that the encyclopedic movement came to the attention of the people, the republic, the academy. We, inexperienced young publishers, made mistakes at work - we corrected, we corrected, we made mistakes ... That's how we moved forward. [12]

The model of the first volume of the Uzbek Soviet encyclopedia contains 2835 articles and 573 bibliographic information, including 134 on philosophy, 63 on economics, 50 on state and law, 51 on pedagogy and psychology, 292 on general and world history. 56 on the history of the USSR, 32 on the history of MarxismLeninism and the CPSU (it was a great courage to give so little space), 60 on astronomy and geodesy, 112 on archeology and ethnography, 381 on language, literature and folklore, There were 162 articles on Oriental Studies, 81 on Mathematics, 109 on Engineering, 103 on Music, Theater and Cinema, 62 on Architecture and Fine Arts, 187 on Biology, 89 on Geology, and 165 on Medicine. Many of these articles are given illustrations, maps, diagrams, bibliographic information, photographs of scientists for biographical cases. The model of the first volume of UzSE 1 was published in large numbers and sent for review to leading scientists from Russia, Ukraine, Armenia, Georgia, Azerbaijan and other sister republics, who looked at the work with interest, pointed out some shortcomings and expressed mostly positive opinions [13].

Creating an encyclopedia is a world-class endeavor. Every word, every article should be in its place. Articles are extremely demanding and at the same time meaningful. These conditions were taken into account in the creation of the Uzbek encyclopedia.

The encyclopedia is an integral part of world civilization. Encyclopedias have been created in different languages and at different times since ancient times. In other words, these books reflect the spirit of the time.

The peoples of Central Asia have also created such encyclopedic books in the person of their great thinkers. The encyclopedic works of Abu Nasr al-Farabi, Abu Rayhan al-Biruni, Ibn Sina, Yusuf Khas Hajib, Mahmud Qashqari, and Alisher Navoi are recognized throughout the world. Al Bayhaqi's book, Tatimma sivan alhikma, was a typical example of medieval encyclopedia. [14] The creation of the Uzbek Soviet encyclopedia was also a revival of those long-standing scientific traditions.

On the 1st volume of UzSE Abdulla Avloni, Abdulla Ansari, Abu Ali ibn Sino, Ahmad Fergani, Alisher Navoi, Ali Kushchi, Literature, Myths, Albania, Armenia, British Revolution, Abovyan, Arslankhan, Abdullah, Entente (military alliance during World War I), Aristophanes, Aristotle, Justice, Assyria, Academy of Athens, Atomic Energy, Anarchy, Ancient Literature, Pierre Abelard, There are articles, pictures and maps about the American continent, the Amazon River.

Volume 2 of the Uzbek Soviet encyclopedia contains knowledge about names, things and events, literary, scientific, social, natural, philosophical concepts beginning with the letter "B".

Artistic image (written by lzzat Sultanov and Laziz Qayumov) is a part of the concept of figurativeness of literature and art. The meaning of imagery is much broader. The image is, first of all, a reflection of the whole literature and art, man and the natural world. According to V.G. Belinsky, the artist does not 
have to prove, he has to show. If something is shown in art, it will be proven. "(Russkie pisateli o literaturnom trude. L.1954, tom 1, 516 - bet)." Through the images of people created (shown) by the writer in mature works of art, we gain extensive information about the life of a certain period (that is, the image of artistic images, along with aesthetic pleasure, provides knowledge, enlightenment, spiritual nourishment) the perfected image is the character. "The perfect form of character is type." At this point, the author explains the literary type as follows: "The type reflects the important characteristics of a particular social group." [15]

Banokat, E.E. Bertels (Nizami, Jami, Navoi researcher), Ludwig van Beethoven, barlos, ballet ("Romeo and Juliet", "Garden Fantasy", "Swan Lake", „, Gulandon: „ Kyrgyz girl, paintings from the ballets "Semurg", "Spartacus"), baroque (creative method, direction), V.V Bartold (historian of the Mongol invasion and the Timurid period), Binoi, John Sebastian Bach, "Happiness - to happiness" brochure on achievement ("Tahsilu-s-saodat", by Muhammad Farobi), bakhshis (unfortunately, these epics are written very briefly), Baghdad, Baha'i (religious movement), Bahovuddin Naqshband, Bahrom Gor ("Avesto") da Varakhran V, 421-438), Bahrom Chobin, Bedil, Babur (life and work are widely covered, photos from his works are given), Pierre Bale, V.G Belinsky, Berdak, geography United Arab Republic (with natural map), Belgium, Belarus, Berlin (where the victory of the Soviets in World War II, the Allies are widely covered with many photos), the most important information about Bulgaria and other countries were given.

Unfortunately, in this 2nd volume of UzSE, in the article "Printing", history is falsified with the demand of ideological pressure. Many years later, when Uzbekistan gained national independence, such eminent scholars as Hamid Ziyoev, Dono Ziyoev, Rustam Shamsuddinov, Haydar Bobobekov, Hamdam Sodiqov,
Kahramon Rajabov restored the historical fact that the Kurds were national liberation fighters, the Soviet army, the Red Army itself was an invader. 16]

In the 3rd volume of the Uzbek Soviet encyclopedia, waqfnama (madrasa students used the fruits of waqf lands), oneness (also called the oneness of Allah, the philosophy of monotheism), oneness, (oneness of the universe), oneness (monotheism, unfortunately, atheism, at the request of his ideology, such articles denounced Eastern philosophers and sages such as Ibn Arabi and Ghazali), panic (fear of mental illness or natural disaster), Mavlon Vahobov (graduated from the Samarkand Pedagogical Academy in 1928, head of the Central Committee of the Uzbek Communist Party in 1944-1945, In 1950-1951, he was awarded the Order of Lenin, twice the Order of the Red Banner of Labor, Valerian Weber - paleontologist, Wilhelm Weber physicist, inventor of the electromagnetic background, for his perseverance and criticism of scientists in the national spirit for his loyalty to the Soviet colonialists. Weber is the author of romantic operas, Vega is the star of Lira (Turkish) The brightest star in the brain, Vegetation, Vedic literature (Rigveda, Samaveda, Ayurveda), Vedanta - the last Vedic period, Vesuvius (an extinct volcano in Europe, Italy), Wexler Vladimir losifovich (synchrophasotron, inventor of cosmic rays, Diego Velasquez - Spanish artist, ancient and modern history), the Congress of Vienna (allies who conquered Napoleon's armies - Austria, England, Prussia, Russia, 1815), the HungarianHungarian language, the Hungarian People's Republic (extensive geography, climate, science, culture, literature, art) illuminated), the planet Venus, "Venus I", "Venus - II" spaceships, Venezuela, Venice, Virgin poet, Giuseppe Verdn - composer, Vereshchagan painter and officer, Veroneze - Italian artist, Peace of Versailles, N.I. Veselovsky (author of "Historical Poetics", orientalist, Amerigo Vespucci - a Spanish traveler who visited America several times with Columbus and 
later), Byzantium (history, culture, literature, law), Freedom of Conscience, Victoria (river, lake in Africa), Rivers in Australia and Canada, Vichnyus, Vinnytsia (a city and region in Ukraine, Vinogratov geochemist and linguist), Virginia (one of the US states), Viruses, Virology, Vitalism (a branch of biology), Vitamins (what each serves), Vobkent tower, the Republic of Vietnam, and other terms).

In the 5th volume of the Uzbek Soviet encyclopedia, the article "Industrialization" states that capitalist relations in the formerly agrarian country of Uzbekistan (formerly Turkestan), the emergence of a small working class, the opening of new plants, factories, mines, metallurgy, it was highlighted that the working class had increased, that they were a highly skilled, advanced class compared to the peasants. On this roof are the laws of inertia on mechanics, the center of inertia, power formulas, engineering geology, engineering psychology, engineering armies (their movement during the war, incrustation, the Inquisition (the savagery of the Catholic Church as infidels, burning incense), Ink culture (indigenous peoples in Latin America). development), advanced cotton grower and painter Inogamov, the Declaration of Human and Civil Rights (adopted by the French bourgeois revolution (1848), on freedom of conscience, freedom of speech and press), integral equations (laws of higher mathematics), the intelligentsia (the intelligentsia, they were viewed with suspicion and repressed by the Soviets), the International Anthem (poem by Eugene Pot, music by Paul DeGeiter), International I and II (International Communist Organization in 1860-70 led the popular liberation movements in England, Germany, Belgium and Switzerland). ), International Brigades (who fought against fascism in Spain from 1936 to 1939, from 54 countries around the world communists, socialists, anti-fascists, including Hungarian writer Mate Zalke (General Lukach, American Ernest Hemingway, Russian Mikhail Koltsov, etc.), Spain, Italy, Iraq, Israel, Jordan (geography, industry, culture), KabardinoBalkaria, the Caucasus, Important information about the terms Cenozoic Era, Calendar (history files), Canada, Capital, Capitalism, Karelia, Caspian Sea, Quasar, Quantum, Kenegas Tribe, Cyvernetic, Cinematography, History of Collective Farms, Yan Amos Comenius, Kamil Khorezmi, Commune, Communism . [17]

Volume 4 of the encyclopedia contains a rather extensive article on Jadidism, the most painful period of our history. This article is preceded by information about Jadid schools. Although this article is written in the spirit of the period, it clarifies a lot of facts for the reader. Apparently, I. Muminov himself authored an article on the socio-political views of the Jadids. [18]

This volume covers the life and work of the famous historical figure Jaloliddin Manguberdi. Along with his heroism in the battle with the Mongols, very touching stories were told about his family tragedies (the Mongols captured Manguberdi's 7-year-old son and snatched his heart alive. The prince's harem is drowned). The book vividly depicts Jaloliddin Manguberdi's struggle against the Mongols in a painting by artist V. Sosedov. [19]

\section{RESULTS AND DISCUSSIONS}

Human life is measured not only by how long he has lived, but also by how he lived. Teacher Ibrahim Muminov lived 66 years. We have no right to discuss the fate of the judge, but he was relatively short-lived. The factors that shortened the life of I. Muminov, who was in the midst of conflicts, and caused him pain and suffering, are a separate topic.

If we look at the pages of I. Muminov's life, we can see that he was very active and energetic. From 1956 to the last days of his life he was vice-president of the Academy of Sciences of Uzbekistan for 18 years. Member of the Supreme Soviet of Uzbekistan for five terms ( 
25 years). Chairman of the Standing Committee on Foreign Affairs of the Supreme Soviet of Uzbekistan for eleven years from 1963. Chairman of the Board of the "Bilim" Society of Uzbekistan, founder and first chairman of the Society of Philosophers of Uzbekistan. Founder and first editor-in-chief of the Uzbek encyclopedia. Initiator and editor-in-chief of the monthly scientific-theoretical journal "Social Sciences in Uzbekistan", which has been published since 1957. Organizer of a number of national and international scientific conferences.

The list goes on and on. A loving father in the family, a mentor to the students. As an extremely responsible person, the Master has perfectly accomplished all the tasks assigned to him. It is noteworthy that he was the initiator in organizing most of this work. It is worth noting that the President of the Republic Sharof Rashidov supported any initiative of our scientists, such as Habib Abdullaev and Ibrahim Muminov, who headed the Academy of Sciences of Uzbekistan. [20]

Sharof Rashidov also took care of the team led by academician Ibrahim Muminov in the formation of the first Uzbek encyclopedia. The creation of the Uzbek Encyclopedia was also very controversial in its time. Gaybullah asSalam, one of our devoted and nationalist scholars who worked as a deputy to I.Muminov since the establishment of Qomus, writes about this: They, too, considered the idea of creating a publication in the Uzbek language to be "like a camel dreaming of a bath." I remember that a well-known linguist at the Presidium of the Academy said that we did not have a scientific terminology, so let's publish the Uzbek encyclopedia in Russian. Imagine: Uzbek Encyclopedia ... in Russian! (What do you think about it! Our two-volume cotton encyclopedia was published in Russian in Uzbekistan? There is no translation in Uzbek!) This was the level of our "advanced" intellectuals. Even now, no better. Fortunately, a yellow-skinned academic named Rijov immediately rejected the offer. "[21]

Muzaffar Khairullaev, Said Shermuhamedov, Haydar Pulatov, Omonullo Fayzullaev, Gaybulla Salomov, Mubin Baratov, A.K. Arends, P.G. Bulgakov, S. Tolstov, G. Pugachenkova, Salih Mutallibov, Hamid Suleiman, and many other intellectuals, began to create the Encyclopedia in 1967. Moscow allows 120 states, each of which has 14 volumes from one hundred printed plates, to cover all printing and publishing expenses.

Sharof Rashidov, Habib Abdullaev, Obid Sodiqov, Ibrahim Muminov, Hodi Zarif, Nurullo Murodov, Ahmadjon Yakubov also had a special contribution to the creation of the Uzbek Encyclopedia.

Officials of the former Soviet ideology looked at each publication with extreme caution. During these years, national cadres were accused of nationalism and national limitations, even for insignificant things.

Scientific works on national history, literature and art were organized on the basis of Moscow's instructions.

"Every nation that creates the encyclopedia is a mirror of the nation. It reflects the history, economy, culture, science, values, celebrities, customs, traditions of the nation, its contribution to the material and spiritual treasury of the world, in short, the whole life death. It must accurately and objectively present historical events, dates, personalities, achievements and shortcomings of science. In preparing the Uzbek encyclopedia, in evaluating some of the events, actions, periods, and individuals that should be included in it, the encyclopedists once again witnessed that the period was extremely complex and contradictory. "[22]

The 55-volume Russian "Great Soviet Encyclopedia" was commissioned by the 
leadership of the All-Union with the participation of scientists from the RSFSR and the sister republics. It took a decade for the Great Soviet Encyclopedia and the Small Soviet Encyclopedia to study and use the experience of compiling an encyclopedia published in Ukraine, to organize editors and editor-inchiefs of various disciplines, to compile dictionaries. It was planned to publish the dictionary and layout of the first volume of the UzSE in 1967, on the occasion of the 50th anniversary of the Great October Revolution, in accordance with the requirements of the time. While the All-Union Party and the Soviet leadership used such celebrations to celebrate the October Revolution, the intellectuals of the fraternal republics used them to develop their science, culture, literature, and art. The leadership of the Union, the colonial Soviets, knew this and would obstruct or adapt it to the demands of Communist policy. Sharof Rashidov, the leader of the Communist Party of Uzbekistan, wisely and moderately followed the demands of the leadership of the Union, the Politburo of the Central Committee of the CPSU, and supported the initiatives of the national intelligentsia of the republic. This compromise was to deal with complex circumstances.

The Uzbek Soviet encyclopedia was created with the help of the staff of the Great Soviet Encyclopedia. For example, they asked for help in writing 162 articles for Volume I of our encyclopedia.

The encyclopedia discusses how to place personal information. There were heated debates. Later, on the basis of a general regulation, it was agreed to place the articles on biographies in the following order:

1. Heroes of Socialist Labor and Heroes of the Soviet Union;

2. Major representatives and military commanders of the Uzbek Communist Party and the Uzbek SSR;
3. Academicians and corresponding members of the USSR Academy of Sciences and allied republics, scientists, cultural figures;

4. Doctors of Science and Professors;

5. Well-known Uzbek composers, writers and artists;

6. People's Artists of the USSR and the USSR;

7. Folk singers.

\section{CONCLUSIONS}

Ibrahim Muminov did a great job in creating the Uzbek Soviet encyclopedia. The 9 volumes of the encyclopedia were prepared under the guidance of the Teacher. Unfortunately, starting from the 5th volume of the encyclopedia, I. Muminov's name was given in a black frame. Life did not fulfill the teacher. "The first 5 volumes of our encyclopedia contain a lot of historical, geographical, ethnographic, literary, scientific, religious, objects and events, genealogies, genealogies, regions, related to our national way of life, national thinking, national customs were given. These were the factors that increased the value of the content and content of our National Encyclopedia, ensuring its weight of independence. At the same time, the chauvinism of the great state and some of our own manipulative local politicians of that time could not forgive him for such tyranny. In the pages of the encyclopedia there were attacks on the idealization of the backward, patriarchal economic status, the feudal past. "[23]

I. Muminov prepared an article about Amir Temur for the first volume of the encyclopedia. Unfortunately, the article, written in the size of a printed plate, was removed from the volume by order of Moscow. Later, after the death of I. Muminov, in the 11th volume of the encyclopedia (Qomus), only the frightening information was given, which begins with "Temur, Amir Temur, Temurlang ...". I. Muminov had dreams as a person and a scientist. A true intellectual always values and glorifies the freedom of his country. In other words, Ibrahim Muminov has always dreamed 
of independence. Through his work, he made a worthy contribution to bringing this independence closer. Today, in independent Uzbekistan, the "National Encyclopedia of Uzbekistan" was created, which I. Muminov could not have achieved as he deserved. [24]

One of the features of the UzSE, which reflected the demands of the Soviet colonial period, was the establishment of the VKP (b), all its congresses and the issues discussed at them. If this were not done, the Uzbek Soviet encyclopedia would not be allowed to be compiled at all. The organizers, editors and authors of the UzSE, with the consent of the Union Center, aimed to introduce the ancient and rich cultural and spiritual heritage of our people, the peoples of Central Asia, the great victories in various sciences and nationalities, to provide encyclopedic knowledge to the younger generation. The true encyclopedia of the nation was created after we gained independence. This is a separate topic.

\section{REFERENCES}

1. History of Uzbekistan (1917 - 1991) T, “Uzbekistan" 2019, p.87

2. Memoirs of I.M.Muminove T, "Fan" 1978

3. Ibrahim Muminov. Let us study in depth the philosophical legacy of VI Lenin. T, 1973.

4. Naim Goyibov. Wise. T, "Uzbekistan" 2008, 38 pages

5. Ibragim Muminov. Role and place of Amira Temura in the history of Sredney Azii.T, "Fan", 1968g.

6. Novoseltsev A.P Ob istoricheskoy otsenke Timura. "Questions of history” $M, 1973$ №2: (M.Abduraimov's article was published in the magazine "History of the USSR" in 1973-5).

7. Erkin Yusupov. In search of light in the darkness. Memories. The first book T, "Turon - Iqbol", 2019, page 11.

8. History of Uzbekistan (1917-1991) T, “Uzbekistan”, 2019, p. 251.
9. Muminov I. Izbrannye proizvedeniya $\mathrm{v}$ chetyryox tomax. Tom 2.T, "Uzbekistan" 1975; I.Muminov tom 3, T, 1977g; I.Muminov volume 4 T, "Uzbekistan", 1977; Ibragim Muminov. Role and place of Amira Temura in the history of Sredney Azii.T, “Fan”, 1968g.

10. Khodjaeva D.Yu. Problems of social philosophy in the scientific heritage of Ibrahim Muminov. 2002, Qahhorov $\mathrm{H}$. Academician Ibrahim Muminov and his role in the development of national culture of the Uzbek people. Samarkand.1999

11. Fayzullaev $O$. Twentieth-Century Intellectuals: My Teachers and Comrades., T, 2008; Ghaybulloh as - Hello. Mankind for Goodness T, Sharq, 1997; Naim Goyibov. Donishmand T, 2008; Hamid Ziyaev. The reign of the great Amir Temur and his destiny T, "Spirituality" 2008.

12. Ghaybullah as - Salom. Mankind for Goodness T, Sharq, 1997, p.257.

13. Muminov I. Izbrannyy proizvedeniya.v 4-X tomax. Volume 4.T. ,, Uzbekistan “, 1977, p. 161-165.

14. Bagirova S.G. Sochinenie "Tatimma sivan al xikma" al - Bayxaki kak obrazets srednevekovogo entsiklopedicheskogo sprovochnika T, "Fan" 1987.str-5

15. Uzbek Soviet encyclopedia.T.1972,1718.bet

16. Hamid Ziyoev. History of the struggle for independence of Uzbekistan. T, "Sharq" 2001; Ziyoeva D.H. Printing: Truth and Fiction. T, "Uzbekistan" 2000. Shamsutdinov R. Martyrs on the way to independence T, 2001. Hero Rajabov. The independence movement in the Fergana Valley: the essence and main stages of development (1918-1924) T, "New Edition" 2015. Rajabov K. Shermuhammadbek T, "Abu Press - Consult" 2001.

17. Uzbek Soviet Encyclopedia, 5 vols. T,! 974.

18. Uzbek Soviet Encyclopedia, 4 vols. T,! 973,278-p ..

19. Ibid., P. 295.

20. Tolqin Alimardonov. An immortal honor. T, 2017, p.165. 
The American Journal of Social Science and Education Innovations (ISSN - 2689-100x)

Published: December 17, 2020 | Pages: 72-82

21. Ghaybullah as-Salam. A human being who is full of goodness. T, "Sharq" 1997g, 244 pages

22. Valiev A.K. Social problems in the works of IM Muminov. - Collection of Academician Ibrahim Muminov (articles and memoirs) T, 1993, p. 45.

23. Ghaybullah as-Salam. Be kind, man. T, Sharq, 1997, p.259.

24. National Encyclopedia of Uzbekistan, Volume 1, T, 2000 